\title{
Male warriors and worried women? Understanding gender and perceptions of security threats
}

\author{
Daniel Stevens $^{1 \star}$ (D), Sarah Bulmer ${ }^{1}$, Susan Banducci ${ }^{1}$ and Nick Vaughan-Williams ${ }^{2}$ \\ ${ }^{1}$ Politics, University of Exeter, Exeter, United Kingdom and ${ }^{2}$ Politics and International Studies, University of Warwick, \\ Coventry, United Kingdom \\ *Corresponding author. Email: D.P.Stevens@exeter.ac.uk
}

(Received 22 February 2019; revised 7 September 2020; accepted 7 September 2020; first published online 19 October 2020)

\begin{abstract}
Differences between women and men in perceptions of security threats are firmly established in public opinion research, with the 'male warrior' and the 'worried woman' two well-documented stereotypes. Yet, we argue in this article, the differences are not as well understood as such labels, or the search for explanations, imply. One reason for this is the lack of dialogue between public opinion research and feminist security studies. In bringing the two fields into conversation by analysing mixed methods research data gathered in Britain, we suggest that while the extent of the gender gap in opinions of security is overstated, the gaps that do exist are more complex than previously allowed: men and women define 'security' in slightly different ways; women tend to identify more security threats than men not necessarily because they feel more threatened but due to a greater capacity to consider security from perspectives beyond their own; women are more confident about the government's ability to deal with security threats in the future but not simply because of greater faith in government than men. This complexity implies a need to revisit assumptions, methods, and analytical approaches in order to develop the field of gender and security further.
\end{abstract}

\section{Introduction}

Public opinion research has found that gender differences on security issues of war, peace, and the use of military force are 'a pattern found throughout the Western world'. ${ }^{1}$ This research suggests that, while women perceive more risks and threats to security then men, ${ }^{2}$ 'the largest and most consistent policy gender gap in public opinion polling' is that women are also less likely to support aggressive action to alleviate those risks and threats. ${ }^{3,4}$ Notwithstanding the

${ }^{1}$ Ulf Bjereld, 'Children and the gender gap in foreign policy issues', Gender and Society, 15:2 (2003), p. 303.

${ }^{2}$ Leonie Huddy, Stanley Feldman, Charles Taber, and Gallya Lahav, 'Threat, anxiety, and support of antiterrorism policies', American Journal of Political Science, 49:3 (2005); Ashley Marie Nellis, 'Gender differences in fear of terrorism', Journal of Contemporary Criminal Justice, 25:3 (2009); Christopher Salvatore and Brian Gorman, 'Gender-based perceptions of the 2001 anthrax attacks: Implications for outreach and preparedness', Security Journal, 27:4 (2014); Pamela Wilcox, M. Murat Ozer, Murat Gunbeyi, and Tarkan Gundogd, 'Gender and fear of terrorism in Turkey', Journal of Contemporary Criminal Justice, $25: 3$ (2009).

${ }^{3}$ Deborah Jordan Brooks and Benjamin Valentino, 'A war of one's own: Understanding the gender gap in support for war', Public Opinion Quarterly, 75:2 (2011), p. 270.

${ }^{4}$ Sapiro prefers 'gender differences' to 'gender gap', both because there is substantial overlap in men's and women's opinions and because differences in opinion between other groups are not referred to as 'gaps'. See Virginia Sapiro, 'Theorizing gender in political psychology research', in David Sears, Leonie Huddy, and Robers Jervis (eds), Oxford Handbook of Political Psychology (Oxford: Oxford University Press, 2003). The authors cited above do not always address their definition of gender. Heidi Hudson's description of 'gender as a unit of analysis is viewed as socially learned behaviour and expectations that

(C) The Author(s), 2020. Published by Cambridge University Press on behalf of the British International Studies Association. This is an Open Access article, distributed under the terms of the Creative Commons Attribution licence (http://creativecommons.org/licenses/by/4.0/), which permits unrestricted re-use, distribution, and reproduction in any medium, provided the original work is properly cited. 
consistency of this finding over decades of research, we are told that 'the underlying mechanisms driving it are only modestly understood'. 5

Searching for 'underlying mechanisms' implies, however, that we understand the gaps we are trying to explain in the first place. This article will argue that the quest for such mechanisms is premature because the meaning of what these differences in perceptions between men and women represent is at best modestly understood. Moreover, we argue that the lack of dialogue between two key bodies of scholarship - public opinion research and feminist security studies (FSS) has led to research designs and analyses that are framed in ways which limit our ability to understand them.

In the twist on the feminist maxim 'the personal is political', Cynthia Enloe reminds us that 'the personal is international'. ${ }^{6}$ Indeed, research has shown that gendered perceptions at the individual level have consequences for the security and aggression of states, including for variation in leaders' proclivity towards aggressive action. ${ }^{7}$ Valerie Hudson et al. argue further that whether or not women feel safe, not just their embrace of non-violence, is an indicator of whether states are likely to engage in conflict: 'If the women and peace thesis ... is valid, the proposition follows that measures of women's physical security should be strongly associated with measures of state security.'

We offer new understandings about the ways men and women perceive security threats and support aggressive action in response by bringing together key insights from feminist security studies and public opinion research. Though concerned with similar empirical topics, these bodies of scholarship have different epistemological starting points, adopt different analytical approaches and tend to use different methods. Broadly, public opinion has typically analysed large- $\mathrm{N}$ quantitative data with the aim of estimating and explaining differences in threat perceptions between men and women. ${ }^{9}$ By contrast, FSS has typically analysed small-N qualitative data about security discourses, demonstrating that they are reflective of gendered and racialised power relations - in terms of which issues count as matters of security, whose security concerns are heard, and the types of security knowledges which are privileged - and have material consequences for different groups in society. ${ }^{10}$

Although both bodies of scholarship are well-established and command significant readership, our study is a timely intervention given that recently their methodological choices have been called into question. FSS has eschewed quantitative methods on the grounds of their associations with generalisability, representativeness, and the production of 'objective' knowledge, ${ }^{11}$ embracing qualitative methods and the production of situated, reflexive knowledge about security instead. But this has also meant that FSS has been unable to examine how security discourses

distinguish between masculinity and femininity' appears to capture what is meant. Heidi Hudson, “'Doing” security as though humans matter: A feminist perspective on gender and the politics of human security', Security Dialogue, 36:2 (2005), p. 156.

${ }^{5}$ Reed Wood and Mark Ramirez, 'Exploring the microfoundations of the gender equality peace hypothesis', International Studies Review, 20:3 (2018), p. 350.

${ }^{6}$ Cynthia Enloe, Bananas, Beaches and Base: Making Feminist Sense of International Politics ( $2^{\text {nd }}$ edn, London: University of California Press, 2000 [orig. pub. 1989]), p. 196.

${ }^{7}$ Valerie Hudson, Mary Caprioli, Bonnie Ballif-Spanvill, Rose McDermott, and Chad Emmett, 'The heart of the matter: The security of women and the security of states', International Security, 33:3 (2008/9).

${ }^{8}$ Hudson et al., 'The heart of the matter', p. 32.

${ }^{9}$ See, for example, Brooks and Valentino, 'A war of one’s own'; Pamela Johnston Conover and Virginia Sapiro, 'Gender, feminist consciousness, and war', American Journal of Political Science, 37:4 (1993).

${ }^{10}$ See, for example, Lene Hansen, 'The Little Mermaid's silent security dilemma and the absence of gender in the Copenhagen school', Millennium, 29:2 (2000); Lene Hansen, 'Are "core" feminist critiques of securitization theory racist? A reply to Alison Howell and Melanie Richter-Montpetit', Security Dialogue (published online 17 March 2020); Jennifer K. Lobasz and Laura Sjoberg (eds), Special issue on 'The state of feminist security studies: A conversation', Politics \& Gender, 7:4 (2011); Laura Shepherd, 'The state of feminist security studies: Continuing the conversation', International Studies Perspectives, 14:4 (2013).

${ }^{11}$ Brooke Ackerly, Maria Stern, and Jacqui True (eds), Feminist Methodologies for International Relations (Cambridge: Cambridge University Press, 2006); J. Ann Tickner, 'What is your research program? Some feminist answers to international relations methodological questions', International Studies Quarterly, 49:1 (2005). 
are understood and negotiated on a large-scale, nor to say much about the (un)certainty of postulated subgroup differences or about the effects of context. Indeed, J. Samuel Barkin and Laura Sjoberg have called for greater engagement with quantitative methods, ${ }^{12}$ critiquing what they characterise as the misleading mapping of the quantitative/qualitative methods binary onto the positivist/post-positivist divide. ${ }^{13}$ At the same time, feminist scholars in public opinion research have argued that traditional methods adopted in their field have ignored contemporary feminist thinking on gender identity that, if incorporated into this research, would 'contribute to alleviating gender normativity'. ${ }^{14}$ The public opinion literature on threat perception also tends to use narrow definitions of threat and security, missing an opportunity to engage with the problematisation of these concepts within feminist security studies.

We argue that a willingness to engage across epistemological divides - which demands methodological and analytical pluralism - and an acceptance of the 'messy' findings this may produce, is necessary for a deeper understanding of gendered perceptions of security threats. This is a challenging task, not least because the vocabularies and concepts in these bodies of scholarship are used in different ways: even within FSS scholarship there are significant differences, for example between 'standpoint' and 'poststructural' feminists, in their understanding of gender and conceptualisation of gendered differences, threats, and security. ${ }^{15}$ Public opinion scholarship does not tend to explicitly theorise or engage with gender in the same way. In survey work, as in this article, gender is often gauged by self-reports of biological sex. ${ }^{16}$ Clearly, from a poststructural feminist perspective - which understands both sex and gender as performative (that is, as discursively produced and having no 'essential' character) - the use of these binary and heteronormative categories for data generation might be considered problematic. ${ }^{17}$ Yet, we would argue that these categories still have social meaning to people, that their everyday usage is politically important, and that understanding how this usage impacts experiences and perceptions of security threats demands precisely the sort of methodological compromise entailed by a pluralist approach.

We are motivated in this article by two basic research questions. RQ1: To what extent are there differences in perceptions of security threats between men and women? RQ2: How should we characterise gender differences in perceptions of security threats and their implications? In bringing public opinion scholarship into closer conversation with FSS to explore these questions, the primary aim is, perhaps somewhat counter-intuitively, to demonstrate how little we know about the nature of the 'gender gap' in security opinion research. Our intention is not to synthesise them into a coherent approach and set of answers, but rather to embrace their tensions and contradictions - as well as areas of agreement - as a way of showing us the limitations of both. This goes beyond a premature search for explanations of a 'gender gap', leads us to ask different questions, and ultimately allows us to offer several paths for future research. To demonstrate the limits in our knowledge and to highlight the potential of a new approach, we share findings from the Security in an Age of Austerity project, conducted in Britain in 2012.

\footnotetext{
${ }^{12}$ J. Samuel Barkin and Laura Sjoberg, 'Calculating critique: Thinking outside the methods matching game', Millennium: Journal of International Studies, 43:3 (2015), p. 854; see also, Amalia Sa’ar, Dalia Sachs, and Sarai Aharoni, 'Between a gender and a feminist analysis: The case of security studies in Israel', International Sociology, 26:1 (2011).

${ }^{13}$ See also Daniel Stevens and Nick Vaughan-Williams, Everyday Security Threats: Perceptions, Experiences, and Consequences (Manchester: Manchester University Press, 2017).

${ }^{14}$ Amanda Bittner and Elizabeth Goodyear-Grant, 'Sex isn't gender: Reforming concepts and measurements in the study of public opinion', Political Behavior, 39:4 (2017), p. 1026; see also Sapiro, 'Theorizing gender'; Katelyn Stauffer and Diana O'Brien, 'Quantitative methods and feminist political science', in Oxford Research Encyclopedia of Politics (2018); Sue Wilkinson, 'Focus groups in feminist research: Power, interaction, and the co-construction of meaning', Women's Studies International Forum, 21:1 (1998).

${ }^{15}$ Jill Steans, Gender and International Relations: Issues, Debates, and Future Directions (Cambridge: Polity Press, 2009).

${ }^{16}$ Bittner and Goodyear-Grant, 'Sex isn't gender'.

${ }^{17}$ V. Spike Peterson (ed.), Gendered States: Feminist (Re)Visions of International Relations Theory (Boulder, CO: Lynne Rienner, 1992).
} 
While we demonstrate and scrutinise the kinds of differences in men's and women's perceptions that have characterised previous research, we emphasise how much overlap men and women have in opinions of security. Thus, in keeping with Virginia Sapiro, ${ }^{18}$ we draw on original data to suggest that the 'gender gap' is somewhat overstated. In addition, we argue that the differences that do exist are far more complex than previously allowed. This begins with men and women conceptualising 'security' in slightly different ways. We also suggest that, although women tend to identify more security threats than men, they feel less intensely about many of these threats than men (who tend to be on permanent 'high alert'), and that this pattern is not necessarily because they feel more threatened but stems from a greater propensity to consider perceptions of security from perspectives beyond their own. Finally, we argue that women are more confident about government's ability to deal with security threats in the future but that this also has complex roots that are not simply due to women having greater faith in government than men.

The article is divided into two main parts. The first is a brief discussion of the principal explanations for what is referred to as the 'gender gap' in public opinion work on security, and a summary of the main FSS contributions to understanding of gender and security. This discussion identifies the core empirical, theoretical, and methodological differences between these approaches. The second part explores what might be gained by bringing insights from both through an analysis of three findings from our research with respect to the two research questions.

It is not our claim that these findings are generalisable in the sense that women's and men's experiences will be identical in other countries, or even that women and men would identify the same specific security threats in the same numbers in other years in Britain. We do contend, however, that just as the 'gender gap' in perceptions of security has been replicated throughout the Western world, the complexity that underlies the gender differences in opinion that we replicate is also likely in those different contexts. We also suspect that specific findings such as the gender differences we uncover in definitions of security threats would be seen outside Britain. More importantly, however, we contend that the need to bring public opinion and FSS research into more meaningful conversation is a general one. We conclude with a discussion of what the complexity we identify implies about the need to revisit and question assumptions, methods and analytical approaches in order to generate new knowledge that can develop the field of gender and security further.

\section{Gender differences and security threats}

Research on public opinion of security threats tells us that, although women and men do not inhabit different 'political universes', ${ }^{19}$ women identify more threats while also being less likely than men to support aggressive action to address those threats. ${ }^{20}$ For example, women express more fear of the threat of a nuclear attack from a hostile state than men, but are 'more dovish' about nuclear weapons testing and weapons exports. ${ }^{21}$ Men are more likely to favour various uses of force, from the death penalty ${ }^{22}$ to tougher immigration policies ${ }^{23}$

\footnotetext{
${ }^{18}$ Sapiro, 'Theorizing gender'.

${ }^{19}$ Conover and Sapiro, 'Gender, feminist consciousness, and war'; Sapiro, 'Theorizing gender'.

${ }^{20}$ Huddy et al., 'Threat, anxiety, and support of antiterrorism policies'; Nellis, 'Gender differences in fear of terrorism'; Salvatore and Gorman, 'Gender-based perceptions of the 2001 anthrax attacks'; Wilcox et al., 'Gender and fear of terrorism in Turkey'.

${ }^{21}$ Conover and Sapiro, 'Gender, feminist consciousness, and war'; Miroslav Nincic and Donna Nincic, 'Race, gender, and war', Journal of Peace Research, 39:5 (2002).

${ }^{22}$ Stanley Feldman and Karen Stenner, 'Perceived threat and authoritarianism', Political Psychology, 18:4 (1997).

${ }^{23}$ Henning Finseraas, Niklas Jakobbson, and Andrea Kotsadam, 'Did the murder of Theo van Gogh change Europeans' immigration policy preferences?', Kyklos, 64:3 (2011).
} 
and military action. ${ }^{24}$ These differences appear to be consistent both cross-nationally and over time. $^{25}$

Theories about the origins of these differences in opinions about war and security have generally focused on why women are more peaceful (the 'women and peace hypothesis'). Most of these theories can be grouped into explanations that focus on: (1) social forces and gender roles; and (2) structural differences that lead to men being more aggressive and women more pacific. The first group of theories emphasise social learning and socialisation: women's subordinate role in society, lack of power, and vulnerable position are cause and effect of day-to-day 'gendered microaggressions ${ }^{26}$ and 'low level victimization'. ${ }^{27}$ These factors, coupled with men's socialisation into the more dominant role and suppression of expressions of fear, ${ }^{28}$ result in differences in attitudes towards security and threats because, 'Gender roles lead to highly differential possibilities for personal security, development, and prosperity, even in today's world. ${ }^{\text {,29 }}$

The second group of theories rely on structural factors as explanations: because women tend to have fewer economic, social, and political resources than men they 'simply have more to lose from war or military violence'. ${ }^{30}$ Thus women's greater opposition to war and conflict and fear of crime in particular is a consequence of their costs falling disproportionately on women, for example, from sexual aggression, ${ }^{31}$ and economically due to the feminisation of poverty. ${ }^{32}$ Although such explanations suggest differences are based on realised experiences and rational-behavioural judgements, more than values or principles, the impact of these structural factors and their related experiences may lead to shifts in identity or role perceptions, linking back to the first group of theories.

FSS scholarship approaches the analysis of gender and security differently and significantly complicates these explanations of the 'gender gap' found in public opinion research. Beginning with the women and peace hypothesis, FSS scholarship encourages us to consider the alternative framing of the puzzle from the 'woman question' to the 'man question', that is, why men are more likely to favour aggressive responses to security threats instead of seeking to explain women's deviation from the masculine norm. ${ }^{33}$ Feminist scholars have also sought to recognise women's agency as violent actors, challenging the assumption that women are socialised to be peaceful, and drawing our attention to the ways in which discourses about (peaceful) women, including our research frameworks, are themselves gendered and reproduce the hierarchies they seek to explain. ${ }^{34}$ As Iris Marion Young argues, 'attempts to connect violence structures

\footnotetext{
${ }^{24}$ Huddy et al., 'Threat, anxiety, and support of antiterrorism policies'.

${ }^{25}$ Johannes Bergh, 'Explaining the gender gap: A cross-national analysis of gender differences in voting', Journal of Elections, Public Opinion and Parties, 17:3 (2007); Richard Eichenberg, Gender, War, and World Order: A Study of Public Opinion (Ithaca, NY: Cornell University Press, 2019).

${ }^{26}$ Valerie Hudson, Bonnie Ballif-Spanvill, Mary Caprioli, and Chad Emmett, Sex and World Peace (New York: Columbia University Press, 2012).

${ }^{27}$ Elizabeth Gilchrist, Jon Bannister, Jason Ditton, and Stephen Farrall, 'Women and the "fear of crime": Challenging the accepted stereotype', British Journal of Criminology, 38:2 (1998).

${ }^{28}$ Hudson et al., 'The heart of the matter'; Robbie M. Sutton and Stephen Farrall, 'Gender, socially desirable responding and the fear of crime: Are women really more anxious about crime?', British Journal of Criminology 45:2 (2005); Wood and Ramirez, 'Exploring the microfoundations of the gender equality peace hypothesis'.

${ }^{29}$ Hudson et al., 'The heart of the matter', p. 20.

${ }^{30}$ Bjereld, 'Children and the gender gap', p. 304.

${ }^{31}$ Megan Bastick, Karen Grimm, and Rachel Kunz, Sexual Violence in Armed Conflict: Global Overview and Implications for the Security Sector (Geneva: Geneva Centre for the Democratic Control of Armed Forces, 2007); Huddy et al., 'Threat, anxiety, and support of antiterrorism policies'.

${ }^{32}$ Shahra Razavi, 'Gendered poverty and well-being: An introduction', Development and Change, 30:1 (1999).

${ }^{33}$ Jane L. Parpart and Marysia Zalewski (eds), Rethinking the Man Question (London and New York: Zed Books, 2008).

${ }^{34}$ Linda Ahall, 'Motherhood, myth and gendered agency in political violence', International Feminist Journal of Politics, 14:1 (2012); Caron Gentry and Laura Sjoberg, Beyond Mothers, Monsters, Whores: Thinking about Women's Violence in Global Politics (Chicago: University of Chicago Press, 2015); Laura Sjoberg and Caron Gentry, Mothers, Monsters, Whores: Women's Violence in Global Politics (London: Zed Books, 2007).
} 
with attributes or behavioral propensities that men or women supposedly share ... rely on unsupportable generalizations about men and women and often leap too quickly from an account of the traits of persons to institutional structures and collective action. ${ }^{35}$ FSS research has also developed structural accounts significantly by exploring the ways in which women's vulnerability and their behaviour are co-constitutive of gendered security practices, such as wartime sexual violence. ${ }^{36}$ Feminists have argued that gender is 'both constitutive and causal' in global politics ${ }^{37}$ in that security discourses and practices reproduce gendered identities, as much as gender 'causes' those different discourses and experiences of in/security. They have also shown that the politics of gender insecurity is not self-contained, but intersecting with, inter alia, nation, class, and race. ${ }^{38}$ Finally, in empirical studies of gendered socialization, such as 'militarized masculinity', FSS scholars have shown that this socialisation is more malleable, contradictory, and unstable than earlier research assumed. ${ }^{39}$

In this brief survey we have offered potential explanations of the causes of gender differences in public opinion research, and the core contributions of FSS scholarship, as well as showing some of the blind spots and misunderstandings that arise in answering the fundamental research questions we pose because of the lack of dialogue between public opinion and FSS research. Crucially, in public opinion work we lack a basic understanding of what gender differences in perceptions of security threats mean and which acknowledges that security discourses themselves are gendered.

Given that this research is exploratory, our expectations are necessarily speculative with regard to what the contrasting methods and perspectives of public opinion and FSS research are likely to offer. They relate more to potential insights from the tensions we have indicated and their implications for the meaning of 'gender differences' in perceptions of security threats. It is also possible, however, that in bringing the two approaches into conversation we will discover some areas in which their findings reinforce each other. Ultimately our main aim is to initiate a discussion and productively complicate existing understandings of the 'gender gap' in public opinion research, rather than to test hypotheses, generate new theories, or offer comprehensive explanations. To address our two research questions, we seek to develop our understanding of three tensions and limitations in extant research.

\section{Articulations of security threats}

Recent qualitative ${ }^{40}$ and quantitative/mixed-method ${ }^{41}$ work indicates that there is systematic variation in how people articulate security threats. But much of the empirical research on RQ1,

\footnotetext{
${ }^{35}$ Iris Marion Young, 'The logic of masculinist protection: Reflections on the current security state', Signs, 29:2 (2003), p. 2.

${ }^{36}$ Lene Hansen, 'Gender, nation, rape: Bosnia and the construction of security', International Feminist Journal of Politics, 3:1 (2001); K Lee Koo, 'Confronting a disciplinary blindness: Woman, war and rape in the politics of security', Australian Journal of Political Science, 37:3 (2002); Laura Sjoberg, Gendering Global Conflict: Toward a Feminist Theory of War (New York: Columbia University Press, 2013).

${ }^{37}$ Laura Sjoberg, 'Feminist security and security studies', in Alexandra Gheciu and William C. Wohlforth (eds), The Oxford Handbook of International Security (Oxford: Oxford University Press, 2018), p. 4.

${ }^{38}$ Hansen, 'Are "core" feminist critiques of securitization theory racist?'; Victoria Basham and Nick Vaughan-Williams, 'Gender, race, and border security practices: A profane reading of "muscular liberalism"', British Journal of Politics and International Relations, 15:4 (2013).

${ }^{39}$ Aaron Belkin, Bring Me Men: Military Masculinity and the Benign Facade of Empire, 1898-2001 (London: Hurst \& Co, 2012); Sarah Bulmer and Maya Eichler, 'Unmaking militarized masculinity: Veterans and the project of military-to-civilian transition', Critical Military Studies, 3:2 (2017); Claire Duncanson, 'Hegemonic masculinity and the possibility of change in gender relations', Men and Masculinities, 18:2 (2015), pp. 231-48; Paul Higate (ed.), Military Masculinities: Identity and the State (Westport, CT and London: Praeger, 2003).

${ }^{40}$ Lee Jarvis and Michael Lister, 'Vernacular securities and their study: A qualitative analysis and research agenda', International Relations, 27:2 (2013).

${ }^{41}$ Stevens and Vaughan-Williams, Everyday Security Threats.
} 
perceptions of security threats, does not go back to this most fundamental of differences; ${ }^{42}$ it assumes that women and men give the same meaning to 'security threat', while not necessarily identifying the same threats or sharing equal concern about them. FSS indicates that security discourses are 'always already' gendered, thus it is important not only to understand how discourses of security determine gendered experiences of insecurity by constructing material realities but also how these discourses themselves privilege gendered values or norms. This means that what we consider 'security' to be, and the measures we undertake to 'secure' ourselves, are also gendered knowledge constructs. For example, V. Spike Peterson ${ }^{43}$ analyses the way in which the Bush administration launched the war on terror by constructing women and feminised others in ways that demanded masculinised identities and action. On the individual level it may be that men are less likely to express insecurities because of masculine norms. ${ }^{44}$ Finally, lived experience is complex and security has significant cognitive and affective dimensions which are challenging to represent. It is possible to think and feel both secure and insecure at the same time, ${ }^{45}$ which may not always emerge from standard survey questions, or be misinterpreted as attitude inconsistency or 'non-attitudes'.

\section{Threats beyond conflict and the state}

Research on public perceptions of security threats tends to be narrowly focused on threats pertaining to war and military conflict; yet everyday security threats are broader and may be more salient. ${ }^{46}$ Indeed, consistent with a general tendency towards higher perceptions of threat among women due to physical and resource vulnerability, extant studies suggest that gender differences extend to economic and job security, where women may both be more at risk ${ }^{47}$ and have more limited choices than men, ${ }^{48}$ although the gender gaps are smaller than for foreign policy issues. ${ }^{49}$ The Transatlantic Trends data used by Eichenberg demonstrate gender differences not only on military force and spending on defence but for an issue such as a possible avian flu pandemic, where the gender gaps in perceptions of threat are as large as for 'the global economic downturn'. ${ }^{50}$ FSS scholarship has also identified that many insecurities women experience come from within, rather than outside of, the nation-state. ${ }^{51}$

In order to understand variations in how and what people think about security issues that fully consider RQ1, a broader range of security threats than war and conflict therefore needs to be considered $^{52}$ that goes beyond the nation and threats to the state. ${ }^{53}$ However, to address RQ2 it is also important to understand the processes through which particular vulnerabilities or fears become

\footnotetext{
${ }^{42}$ See, for example, Eichenberg, Gender, War, and World Order.

${ }^{43} \mathrm{~V}$. Spike Peterson, 'Gendered identities, ideologies, and practices in the context of war and militarism', in Laura Sjoberg and Sandra Via (eds), Gender, War, and Militarism: Feminist Perspectives (Santa Barbara, CA: Praeger Security International, 2010), p. 28.

${ }^{44}$ Rachel Pain, 'Place, social relations and the fear of crime: A review', Progress in Human Geography, 24:3 (2000).

${ }^{45}$ Laura Sjoberg, 'Centering security studies around felt, gendered insecurities', Journal of Global Security Studies, 1:1 (2016).

${ }^{46}$ Caron Gentry, 'Epistemological failures: Everyday terrorism in the West', Critical Studies on Terrorism, 8:3 (2015); Jarvis and Lister, 'Vernacular securities and their study'.

${ }^{47}$ Genevieve LeBaron and Adrienne Roberts, 'Toward a feminist political economy of capitalism and carcerality', Signs, 36:1 (2010).

${ }^{48}$ Sylvia Chant, 'The "feminisation of poverty" and the "feminisation" of anti-poverty programmes: room for revision?', Journal of Development Studies, 44:2 (2008).

${ }^{49}$ Bjereld, 'Children and the gender gap'; Sapiro, 'Theorizing gender'.

${ }^{50}$ Eichenberg, Gender, War, and World Order.

${ }^{51}$ Peterson (ed.), Gendered States.

${ }^{52}$ Adam Crawford and Steven Hutchinson, 'Mapping the contours of "everyday security": Time, space and emotion', British Journal of Criminology, 56:6 (2016).

${ }^{53}$ See, for example, Karen Snedker, 'Altruistic and vicarious fear of crime: Fear for others and gendered social roles', Sociological Forum, 21:2 (2006).
} 
'securitized'. FSS scholars have shown that gendered norms (intersecting with class and race) shape what is considered to be a security issue - as opposed to a 'domestic policy problem', for example - and who has the social authority to 'speak security' ${ }^{54}$ Traditional security discourses around ideas of 'national security' have excluded the 'feminised' domestic realm and we need to pay as much attention to what is not considered a security threat by 'studying silences. ${ }^{55}$ We also need to gauge not simply the security threats that women and men identify but the intensity with which they are experienced, that is, whether they are seen to represent acute danger demanding response or something less urgent.

\section{Government's ability to deal with security threats}

It is well established in public opinion literature that women tend to perceive more threats than men and that women are also more 'risk averse' than men. ${ }^{56}$ This framing has led to a focus on measuring support for aggressive interventions or on changes in the individual's behaviour to mitigate risks such as terrorism ${ }^{57}$ in order to understand the apparent puzzle that women feel more threatened but are less willing to support aggressive responses.

Existing work, which overwhelmingly focuses on support for military responses, limits understanding in two key ways: first, it marginalises everyday security concerns; second, as a result, we do not know whether gender differences in support for government action either extend to other kinds of security threats, or derive from the threat itself or from a broader gendered scepticism about the ability of government to combat these threats. To understand more fully the meaning and consequences of threat perception, thus providing further evidence to address RQ2, demands exploration of how these perceptions translate to views of government and what government can do. Does risk aversion mean not just that women are less supportive of military intervention but that they are generally sceptical about the government's ability to mitigate threats? Does men's propensity for high risk responses, such as military action, suggest greater confidence in the efficacy of government actions?

Addressing these gaps in our knowledge would enable a greater understanding of what influences preferred responses to threats but also allow us to connect these experiences of threat and security with the feminist research about the gendered nature of the state and government more generally. ${ }^{58}$ Previous research on these questions is divided and under-theorised. On the one hand, greater risk aversion among women and women's experience of threats on a daily basis, coupled with men's perceptions of invulnerability, may lead us to expect women to be more sceptical than men about the government's ability to deal with those threats. On the other hand women may be more apt to see the state as 'the imagined provider of security ${ }^{59}$ or as an extension of their caregiving role, ${ }^{60}$, for example through austerity measures. ${ }^{61}$

\footnotetext{
${ }^{54}$ Hansen, 'The Little Mermaid's silent security dilemma'; Hansen, 'Are “core” feminist critiques of securitization theory racist?'.

${ }^{55}$ Hansen, 'The Little Mermaid's silent security dilemma'; Annica Kronsell, 'Method for studying silences: Gender analysis in institutions of hegemonic masculinity', in Ackerly, Stern, and True (eds), Feminist Methodologies for International Relations.

${ }^{56}$ See, for example, Rachel Croson and Uri Gneezy, 'Gender differences in preferences', Journal of Economic Literature, 47:2 (2009).

${ }^{57}$ See, for example, Patricia Gwartney, 'Race, gender, class and perceptions of terrorism in the immediate aftermath of September 11, 2001', Race, Gender \& Class, 14 (2007); Nellis, 'Gender differences in fear of terrorism'.

${ }^{58}$ Peterson (ed.), Gendered States; Young, 'The logic of masculinist protection'.

${ }^{59}$ Maud Eduards, 'What does a bath towel have to do with security policy? Gender trouble in the Swedish armed forces', in Anica Kronsell and Erica Svedberg (eds), Making Gender, Making War: Violence, Military and Peacekeeping Practices (London: Routledge, 2011).

${ }^{60}$ Salvatore and Gorman, 'Gender-based perceptions of the 2001 anthrax attacks'. This would itself need to be explained given the insecurities the state can inflict disproportionately on women.

${ }^{61}$ Rosalind Cavaghan and Muireann O’Dwyer, 'European economic governance in 2017: A recovery for whom?', Journal of Common Market Studies, Annual Review (2018), p. 56.
} 
Indeed, Christopher Salvatore and Brian Gorman find that while women express greater fear of threats such as terrorism they also seem to be more positive about the government's reactions to them. $^{62}$

\section{Research design: Combining small group discussion with a large-N survey}

In order to address these research problems, we need an approach that allows us to see how men and women articulate what they mean by and identify as 'security threats', that looks at those threats beyond war and military conflict at the national and international level, and that asks about government effectiveness in dealing with perceived threats. ${ }^{63}$ To accomplish this we analyse mixed methods data, integrating qualitative focus group and quantitative survey research data from Britain in order to examine the nature and implications of men's and women's perceptions of security and security threats. ${ }^{64}$ While both methods are often used in isolation, neither is sufficient for our purposes for two reasons.

First, although qualitative research allows women and men to define and articulate 'security threats' in their own words, and is often the preferred method of feminist IR scholars ${ }^{65}$ it does not permit estimation of the extent, size, or uncertainty of those differences. Second, large- $\mathrm{N}$ survey research enables more precise estimation of gender differences but does not on its own permit the richer examination and explanation underlying those differences that we seek. We use data from these two different methods to address the gaps and tensions in each mode of analysis that would otherwise only allow a more limited exploration of the research puzzle. $^{66}$

The 'Security in an Age of Austerity' project conducted twenty focus groups for ninety minutes in two waves of ten. Their defining demographic for us is gender, but within gender groups also varied by religion, ${ }^{67}$ life stage, and region, both in order to enhance discussion of sometimes sensitive topics such as fear of knife crime or racism and to be sensitive to intersectional differences that might moderate gender differences, which we discuss below (see Appendix, section A1 in the supplementary material for the composition of groups).

In the first wave of ten groups men and women were allowed to define and identify the scope and nature of security threats. The findings of this first wave of focus group research were used to inform subsequent data collection and analysis, beginning with the development of a twenty-five-minute survey of 2004 respondents that allowed further examination of the three research topics, including estimates of the uncertainty of relationships between variables. The

\footnotetext{
${ }^{62}$ See also Gwartney, 'Race, gender, class and perceptions of terrorism'.

${ }^{63}$ Securitisation theory has been critiqued for its prioritization of the speech acts of elite actors; see Thierry Balzacq, Securitization Theory: How Security Problems Emerge and Dissolve (London: Routledge, 2010). It has also been criticised for ignoring 'security as silence'; see Hansen, 'The Little Mermaid's silent security dilemma', for its silencing of the 'subaltern'; Sarah Bertrand, 'Can the subaltern securitize? Postcolonial perspectives on securitization theory and its critics', European Journal of International Security, 3:3 (2018); Alison Howell and Melanie Richter-Montpetit, 'Is securitization theory racist? Civilizationism, methodological whiteness, and Anti-black thought in the Copenhagen School', Security Dialogue, 51:1 (2020), and for the notion that security can be separated 'from the workings of gender'; see Maria Stern, and Annick Wibben, 'A decade of feminist security studies revisited', virtual collection for Security Dialogue (2015), accessed 24 April 2018). While our approach relies on articulated understandings of security threats, for example, in the survey, we observe gendered silences, for example, in female subjects in the surveys and focus groups not identifying domestic violence as a salient security threat, and racialised experiences of insecurity among minority groups (see below).

${ }^{64}$ A FSS perspective did not directly inform the research design. The engagement with FSS arose after we noticed interesting gender differences in our data.

${ }^{65}$ Sa'ar et al., 'Between a gender and a feminist analysis'.

${ }^{66}$ For a fuller discussion of mixed methods research designs in public opinion and security studies research, see Stevens and Vaughan-Williams, Everyday Security Threats, ch. 2.

${ }^{67}$ Given the likely distinct experiences of religious minorities associated with particular ethnicities after $9 / 11$ and 7/7, some groups were composed of Muslims or Hindus and Sikhs; this provided a glimpse into racialised experiences of insecurity, which requires further research.
} 
sample was representative of the population in terms of sex, age, region, and vote in the previous UK general election (see Table A1 of the Appendix in the supplementary material). Drawing on the focus groups, the survey asked about definitions of 'security threat', as well as about perceptions of a range of issues extending beyond war and conflict, as 'serious threats' at the moment. It gauged opinion about these issues, first as threats to 'the security of the world' and then to 'the UK', 'the community in which you live', and 'you and your family', allowing us to examine perceptions of threats beyond the state. The list of potential threats was constructed from a combination of those recognised in the UK government's National Security Strategy (NSS) and threats that were frequently mentioned in discussion in the focus groups. They included terrorism and attacks on UK cyber space from the former, and the economy, immigration, burglary and online fraud from the latter. In addition, the survey asked about perceptions of the effectiveness of the British government's approach to security in terms of its handling of a range of security issues now and in the future (see Appendix, section A8 in the supplementary material for exact question wordings).

Finally, additional focus groups were conducted after the initial results of the quantitative research had been processed in order to tease out further meaning. The groups covered many of the same topics as the first wave but with a greater emphasis on understandings and perceptions of 'security threat', levels of security threats today compared to the past, and the extent to which responsibility to reduce threats falls on individuals rather than governments.

We analyse the survey data by looking mostly at the bivariate relationships between gender and perceptions of security threats, but we control for other variables in multiple regression models where appropriate, for example where we seek to see whether gender differences are robust to the introduction of variables such as age. With regard to the qualitative data, two of the authors first reviewed all the transcripts. They then separately identified recurring ideas in the focus groups related to the three topics of: articulations of security threats, specific threats mentioned and discussed, and perceptions of government with respect to security threats. Where differences between women and men were evident, the authors organised them into themes (an idea could be in more than one theme) also identifying quotes that were illustrative of each theme - thus the quotes we use throughout the analysis are representative of the themes we found. ${ }^{68}$ The two authors then reconciled the themes present in the groups through discussion and further analysis. David Stewart and Prem Shamdasani term this method of analysis of focus groups 'scissor-and-sort'. 69 They suggest a weakness is that it often depends on a single analyst; in our case, we guarded against that by having two authors analyse the transcripts (see Appendix in the supplementary material for further discussion).

\section{Analysis}

\section{Articulations of security threats}

We use the quantitative and qualitative data to examine the fundamental FSS question of how men and women think and talk about what 'security' and 'security threat' means. In the survey, respondents were provided with ten descriptions of 'security' and asked for up to three that best captured their own definition. Drawing on previous research, ${ }^{70}$ they covered a range of

\footnotetext{
${ }^{68}$ The gender differences we identified from the focus group are tendencies rather than necessarily being characteristic of all individuals and all groups - any more than relationships present in survey data characterise all respondents in the survey. Quantitative survey research can, however, tell us about the statistical significance of relationships, while the tendencies we discuss from the qualitative data are those we regard as 'significant' from our reading of them. Readers can examine the publicly available transcripts at: $\{$ https://beta.ukdataservice.ac.uk/datacatalogue/studies/study?id=851004\}.

${ }^{69}$ David Stewart and Prem Shamdasani, Focus Groups: Theory and Practice ( $3^{\text {rd }}$ edn, Thousand Oaks, CA: Sage, 2014), p. 116.

${ }^{70}$ See, for example, Lee Jarvis and Michael Lister, 'Disconnected citizenship? The impacts of anti-terrorism policy on citizenship in the UK', Political Studies, 61:3 (2013).
} 
definitions, from security as the absence of threats at various levels to equality, physical safety, and freedom.

Table 1 shows the proportions of men and women that selected each definition as the primary meaning of security for them, and that chose each as one of their top three criteria, under 'Any Mentions'. It demonstrates that women and men tended to order these criteria in the same way, with physical safety being the most frequently chosen definition of security. But there were differences in the proportions selecting specific criteria. While some of these differences rise to statistical significance (in the shaded boxes in Table 1), the largest is 11 per cent. Consistent with the idea of 'gendered microaggressions', ${ }^{71}$ women were more likely to define security in terms of physical safety and the absence of threats to humans in general, and, in line with the idea of financial hardship falling disproportionately on women, ${ }^{72}$ were also somewhat more likely to mention access to resources such as 'healthcare for human well-being'. Men were more likely than women to refer to the absence of threats 'to me' and to freedom from foreign dictatorship and absence of threats to the community (although for both men and women the latter two were less common definitions). These findings may reflect previous research on crime that women and men focus on different objects of threat - to children, partner, individual or country. ${ }^{73}$ We return to this difference in perspectives - 'humans in general' versus 'my community' and 'me' - later.

Differences were not evident, however, in the specific security threats that sprang to mind for men and women in the focus groups: even if women and men define security somewhat differently they tended to identify the same issues as security threats. Both male and female focus group respondents seemed to connect the ideas of security and security threat primarily with crime and terrorism. While there was some variation, men and women tended to prioritise and categorise security threats in a broadly similar way. When asked what 'came to mind' when they thought about the word security, Sue recognised that 'all types of things' could be securitised or conceptualised as threats, before she and two women in her group identified 'safety', 'security tags', 'bombs', 'burglaries', and 'breaking in. Stealing your car, taking something out of the car'. Among men, similar themes were in evidence when asked what came to mind when they thought of 'security threats': their responses included 'burglary', 'theft', 'Al Qaeda', 'Iran', '9/11', and 'images of 7/7 bombings'.

Looking more closely at how women and men talk about security threats and associated concepts such as risk, the qualitative evidence suggests men are more fearful than women when it comes to assessing the current threat level and in their general attitudes toward risks: women appear to adopt a pragmatic attitude towards threats. This challenges findings from previous research, based predominantly on survey data, that women feel more threatened. ${ }^{74}$ For example, here is an exchange about perceptions of threat levels among a group of middle aged Hindu women (reacting to a colour-coded 'threatometer' to locate what they felt to be the current level of threat):

Sonia: I would say little risk.

Little risk, why do you say that?

Pam: Mine would be on the line, that line.

The line between little risk and risk.

Pam: Yes.

Okay. And where would you?

Pam: Because you are alert aren't you.

\footnotetext{
${ }^{71}$ Valerie Hudson, Bonnie Ballif-Spanvill, Mary Caprioli, and Chad Emmett, Sex and World Peace (New York: Columbia University Press, 2012), p. 17.

${ }^{72}$ Hudson et al., 'The heart of the matter'.

${ }^{73}$ Gilchrist et al., 'Women and the "fear of crime"'; Snedker, 'Altruistic and vicarious fear of crime'.

${ }^{74}$ See, for example, Nellis, 'Gender differences in fear of terrorism'; Wilcox et al., 'Gender and fear of terrorism in Turkey'.
} 
Table 1. Definitions of 'security'.

\begin{tabular}{|c|c|c|c|c|}
\hline & \multicolumn{2}{|c|}{ First Mention } & \multicolumn{2}{|c|}{ Any Mention } \\
\hline & $\begin{array}{l}\text { Women } \\
(\%)\end{array}$ & $\begin{array}{l}\text { Men } \\
(\%)\end{array}$ & $\begin{array}{l}\text { Women } \\
\qquad \%)\end{array}$ & $\begin{array}{c}\text { Men } \\
(\%)\end{array}$ \\
\hline Feeling physically safe where you are (where you live, work, etc.) & $50^{*}$ & 39 & $81^{*}$ & 73 \\
\hline The absence of threats to humans in a general sense & 14 & 15 & $54^{*}$ & 47 \\
\hline The absence of threats to me (i.e., individuals) & 8 & $11^{*}$ & 38 & $43^{*}$ \\
\hline $\begin{array}{l}\text { The ability to access health care, education, and sufficient resources } \\
\text { necessary for human well-being }\end{array}$ & 8 & 8 & $31^{*}$ & 25 \\
\hline The freedom to do what you want within the confines of the law & 7 & 8 & 27 & 28 \\
\hline The absence of threats to my community & 3 & 4 & 23 & $30^{\star}$ \\
\hline The nation's freedom from foreign dictation & 2 & $6^{\star}$ & 14 & $21^{\star}$ \\
\hline It depends. Some people's security depends on other people's insecurity & 4 & 4 & 14 & 13 \\
\hline Being treated the way others are treated & 1 & 1 & 8 & 7 \\
\hline The threat, use, or control of military force & 2 & 2 & 6 & 7 \\
\hline
\end{tabular}

Notes: Figures are from the question, "Which one of the following best describes what you understand by the term "security"? And which next best describes what you understand? And next?' Respondents could choose up to three definitions, or one or two if they preferred.

* (and shaded boxes). Difference statistically significant at $p<.05$ (chi-square test).

Source: ICM Survey, Security in an Age of Austerity, 5-16 June 2012.

Hitala: The same thing, on the same level, yes.

Okay. So why do you think little risk?

Pam: I don't feel, although I am alert I don't feel uneasy, I am not scared to go out the house or anything like that [laughter] I get on with my life without worrying, because some people won't go out their door will they.

In another example, from a group of retired white women, the point about pragmatism is illustrated throughout but perhaps most clearly by the final comment:

Val: I don't think there's any point in being anxious about terrorism, to be honest. Because I can't do anything. If my next-door neighbour's making a bomb, there isn't a great deal I can do ... If you're saying that there's people on the streets that are going round planning to blow people up, then again, I can't do anything so getting anxious about it, I don't think, does me in.

Judy: The trouble with terrorism is that it's invisible isn't it? You could be stood next to a man at the bus, who could be a suicide bomber.

Judy: I think terrorism's something that ordinary people like us just can't do anything about. The government can't do anything about it even though they're trying.

Contrast this with an exchange on the same theme among middle-aged white men, in which the sense of threat, unwillingness to countenance a level of 'little threat', and perceived need to be alert is palpable:

Mike: You've got to be responsive to everything ... Everyone is uneasy about everything ... that's how I'd see it but all three of us might have a different idea. 
Richard: I would say it is between the two, I would say it is probably quite close to getting high risk.

John: Certainly not either of the yellow ones is it, certainly not no risk or little risk. I think we've all got heightened awareness of what's going on.

Or among older white men with children:

Ian: I think it [the UK] is still at high risk personally.

\section{... And what is it that is telling you that we are at high risk or risk?}

Neil: Well as Ian just said we've had the Olympics and the country was put on a high alert because we've got so many people coming into the country. It becomes attractive to some terrorists but some of the terrorists have got wise to that and the fact that you are thinking about it is enough for them because you are expending a lot of economic activity and dressing up a perception and that's what it's there to do. It's not necessarily to dismantle buildings and kill people. It's about causing economic destruction.

In the following exchange among retired white men, after one respondent's description of the current situation as 'high risk', we also see a wish for action that contrasts starkly with Judy's sentiment that, 'The government can't do anything about it even though they're trying':

\section{Would you two agree with that that it's higher risk now?}

Ralph: It is high risk yes, yes.

Alan: Yes.

Ralph: And not only is it higher risk and it has been for a long time but something needs to be done about it nationally whereas nothing seems to be done at all, we don't know what's, you know nothing's going on at the moment ...

In sum, men and women in our study define 'security' somewhat differently, with the survey evidence in Table 1 showing women more likely to define security in terms of physical safety, absence of threats to humans, and access to resources like education and health for human wellbeing, while men are more likely to see it as an absence of threats to them as individuals and to their community. These differences are statistically significant, while also indicating a degree of overlap that is consistent with previous research. ${ }^{75}$ However, when we examine articulations of security threats in the focus groups, contrary to the prevailing literature ${ }^{76}$ men appear to be more fearful than women, with women adopting a pragmatic response to security threats. This need not imply that women identify fewer threats than men - we will turn to that evidence shortly - but the women in our groups indicated lower levels of anxiety because there was little that they or the government could do, whereas the men spoke of high levels of risk and the need to be alert and ready to act.

It is not clear why men feel more threatened, and this is somewhat contrary to structural theories of the gender gap outlined above, which suggest men are less vulnerable to threats. As Peterson explains with regards to the war on terror, it may be that security threats are being

\footnotetext{
${ }^{75}$ Sapiro, 'Theorizing gender in political psychology research'.

${ }^{76}$ See, for example, Huddy et al., 'Threat, anxiety, and support of antiterrorism policies'; Wilcox et al., 'Gender and fear of terrorism in Turkey'.
} 
constructed in ways that 'demand masculinized identities and action'. ${ }^{77}$ The logic of masculinist protection analysed by Young suggests that "the "good" man is one who keeps vigilant watch over the safety of his family and readily risks himself in the face of threats from the outside in order to protect the subordinate members of his household. ${ }^{78}$ Or, it may be that risk, and risk taking, are associated with masculinity more generally. ${ }^{79}$ Without further research, particularly on how gender intersects with race in public perceptions of threat, we cannot draw any definitive conclusions, but what this exploratory analysis of British data demonstrates is that using mixed methods and insights from FSS about the gendered nature of security discourses leads to a more complex and nuanced picture than traditional public opinion scholarship perspectives might allow. While men and women define security somewhat differently, inferences that we might draw from survey data alone could be misleading: by observing articulations of threat in addition, we show pragmatism among our female respondents that would otherwise be missed and that compels us to re-interpret the survey data and to generate new lines of enquiry.

\section{Threats beyond conflict and the state}

Going beyond issues of war and military conflict and the confines of global and national threats, we now use the quantitative data to compare the number of threats that respondents viewed as global, national, community, and personal in response to separate questions about which issues they 'consider to be serious threats to the security of the world, the UK, 'the community in which you live', and 'you and your family' (for a full list of the issues, see Appendix, section A8 in the supplementary material). Their responses show that women and men generally identified the most security threats on average at the global level - between 6 and 7 - followed by the national level, with fewest threats - about 2 - identified as community or personal (see Appendix Table, section A2). In keeping with the implications of previous research, but in contrast to the more pragmatic attitudes toward risk and threat that we discussed in the previous section, women tended to perceive more threats at all levels, although the differences are statistically significant only for perceptions of the number of global threats. We see no sign either that threats at the local level are more salient for women, that is, that any greater concern about everyday security threats $^{80}$ is at that level, or that the slightly higher likelihood of men to include an absence of threats to the community in their definition of security shown in Table 1 results in the identification of a greater number of community level threats.

Table 2 focuses on differences in the specific threats identified by men and women from the survey data (see Appendix, Table A3 in the supplementary material for the full table). It confirms that women and men do not inhabit vastly different universes in their perceptions of salient threats. ${ }^{81}$ Their answers indicate both that they rank security threats in a similar order and also that there are not issues for which a majority of women are on one side and men on another; indeed, the largest differences were 14 per cent and most were smaller, which is similar to the findings of previous research on threats pertaining to war and military intervention. ${ }^{82}$

Table 2 also shows that the issues women perceive as security threats range well beyond those pertaining to war and military intervention - indeed, while there was a difference in the perceived threat from terrorism there was none on issues such as the threat of an international military crisis between states or nuclear weapons programmes in hostile states - tending to fall under the

\footnotetext{
${ }^{77}$ Peterson, 'Gendered identities, ideologies, and practices', p. 28, emphasis added.

${ }^{78}$ Young, 'The logic of masculinist protection', p. 4.

${ }^{79}$ Cynthia Enloe, Seriously!: Investigating Crashes and Crises as If Women Mattered (London and Los Angeles: University of California Press, 2013).

${ }^{80}$ Henri Lefebvre, Everyday Life in the Modern World (London: Transaction Books, 1984); Rachel Pain, Everyday Terrorism: How Fear Works in Domestic Abuse (Centre for Social Justice, Durham University, 2012).

${ }^{81}$ Conover and Sapiro, 'Gender, feminist consciousness, and war'.

${ }^{82}$ See, for example, Eichenberg, Gender, War, and World Order.
} 
Table 2. Differences in issues perceived as security threats by women and men (numbers by \%).

\begin{tabular}{|c|c|c|c|c|c|}
\hline \multicolumn{3}{|c|}{ Women more threatened than men* } & \multicolumn{3}{|c|}{ Women less threatened than men* } \\
\hline \multicolumn{6}{|c|}{ Global level } \\
\hline Online fraud/identity theft & $37-23$ & +14 & & & \\
\hline Knife crime & $34-21$ & +13 & & & \\
\hline Racial or religious hate crime & $47-35$ & +12 & & & \\
\hline Crimes against women & $23-11$ & +12 & & & \\
\hline Burglary & $21-13$ & +8 & & & \\
\hline Terrorism & $72-65$ & +7 & & & \\
\hline Religious extremism & $59-52$ & +7 & & & \\
\hline Nuclear accident & $30-23$ & +7 & & & \\
\hline Economy & $48-43$ & +5 & & & \\
\hline Environmental issues & $32-27$ & +5 & & & \\
\hline \multicolumn{6}{|c|}{ National level } \\
\hline Knife crime & $29-18$ & +11 & Religious extremism & $32-39$ & -7 \\
\hline Online fraud/identity theft & $23-13$ & +10 & & & \\
\hline Racial or religious hate crime & $31-22$ & +9 & & & \\
\hline Crimes against women & $10-4$ & +6 & & & \\
\hline Burglary & $11-8$ & +3 & & & \\
\hline \multicolumn{6}{|c|}{ Community level } \\
\hline Burglary & $31-26$ & +5 & Religious extremism & $7-13$ & -6 \\
\hline Online fraud/identity theft & $18-13$ & +5 & Weak border control & $4-8$ & -4 \\
\hline \multirow[t]{3}{*}{ Crimes against women } & $11-7$ & +4 & Resource scarcity & $5-9$ & -4 \\
\hline & & & Terrorism & $6-9$ & -3 \\
\hline & & & Nuclear weapons & $1-3$ & -2 \\
\hline \multicolumn{6}{|c|}{ Personal level } \\
\hline Online fraud/identity theft & $24-19$ & +5 & Religious extremism & $6-10$ & -4 \\
\hline Crimes against women & $9-4$ & +5 & Weak border control & $3-6$ & -3 \\
\hline Health pandemic & $10-7$ & +3 & Immigration & $9-12$ & -3 \\
\hline
\end{tabular}

Notes: Figures are from the questions, 'Which, if any, of the following issues do you personally consider to be serious threats to the security of the world/ UK/ community in which you live/ you and your family at the moment?' *Issues listed show statistically significant differences between women and men at $\mathrm{p}<.05$ in chi-squared tests.

Figures show the differences between women and men in the third column, with the second column showing \% identifying each issue as a threat, with women first and men second, for example (24-19) means $24 \%$ of women and $19 \%$ of men.

Issues not shown imply a statistically insignificant difference. (For a full list of the issues from which respondents could choose, see Appendix, Table A3 in the supplementary material.)

Source: ICM Survey, Security in an Age of Austerity, 6-15 June 2012.

banners of crimes of various kinds, the economy, and environmental issues including the possibility of nuclear accidents. Some of these are consistent both with theories that women are more threatened than men by issues linked to the possibility of physical harm, ${ }^{83}$ and with our evidence showing the greater likelihood of women to define security in terms of resources for human wellbeing, for example, fear of online fraud and identity theft, or 'threats to humans in a general

${ }^{83}$ Hudson et al., Sex and World Peace. 
sense', for example, greater sensitivity to environmental issues and nuclear accidents. But the gender differences we found in definitions of 'security' cannot fully explain the results.

At the national level also, Table 2 shows that there are more issues for which women's perceptions of threat were significantly greater than men's - five, compared to one for which men were more threatened than women - but on most of the 22 issues, including the major national issues of the economy, terror, immigration, and border control there were no gender differences. The national level issues on which women felt more threatened than men are all related to crime and again seem connected to women's somewhat greater concerns with threats to physical safety and resources - online fraud, knife crime, burglary, hate crime, and crimes against women. The one issue on which men were more threatened than women is religious extremism. Table 2 shows similar patterns for perceptions of community and personal security threats: women and men identified fewer threats in general at these levels but differences remain in women being more likely to identify problems such as online fraud while men identified issues such as immigration, weak border control, and religious extremism. The marginally greater number of communitylevel threats identified by men than women is consistent with their greater likelihood to define security in terms of an absence of threats to their community, but the differences in issues are in the range of 4 to 5 per cent rather than the gaps of 10 per cent and above sometimes seen in perceptions of global and national level threats.

The absence of evidence that perceptions of issues related to national security, terrorism, and war were consistently viewed differently as threats by men and women is noteworthy. Another absence of interest pertains to the relatively low perceptions of 'crimes against women' as a security issue. Although Table 2 shows women tend to be more likely to regard such crimes as threats at all levels, only 10 per cent identified them as a national security issue, less than 16 other issues. The focus groups also showed neither women nor men understanding domestic violence within a security narrative. As a form of insecurity which is both relatively common (as compared to terrorist attacks, for example), and that disproportionally harms women, ${ }^{84}$ this demonstrates, as FSS scholarship has argued, the extent to which security discourses reflect and constitute gendered power relations. ${ }^{85}$ Indeed, when talking about local level threats participants in the focus groups always located these crimes outside the home and as acts typically perpetrated by strangers. This provides interesting evidence that Young's logic of masculinist protection - in which threats are primarily outside the household, which is protected by the male head - is a powerful idea, if not the reality in objective terms. ${ }^{86}$ Again, we cannot draw definitive conclusions without further exploration, but this illustrates well how an FSS perspective is useful not only for analysing what our data show, but what it does not show, and the gendered and racialised 'silences' that surround security discourses. ${ }^{87}$ This in turn can support the generation of different public opinion research that can engage with these silences more effectively.

How can we reconcile the finding that women identify more threats, particularly at the global level, with the qualitative evidence that they also appear to feel less threatened when discussing threat levels? A clue may lie in responses to perceived threats. Karen Snedker finds that fear of crime among women stems from concern about a broader range of family members than fear among men. ${ }^{88}$ Beyond family, as well as the survey evidence on women being more likely to define security threats in terms of human resources and well-being, the focus groups we

\footnotetext{
${ }^{84}$ Department of Health, Social Services and Public Safety and the Department of Justice, 'Stopping Domestic Abuse and Violence in Northern Ireland: A Seven-Year Strategy', available at: \{https://www.health-ni.gov.uk/sites/default/files/publications/dhssps/stopping-domestic-sexual-violence-ni.pdf\} accessed 29 July 2019; Office for National Statistics, 'Domestic Abuse in England and Wales: Year Ending March 2018', available at: \{https://www.ons.gov.uk/peoplepopulationandcommunity/crimeandjustice/bulletins/domesticabuseinenglandandwales/yearendingmarch2018\} accessed 29 July 2019.

${ }^{85}$ Sjoberg, 'Feminist security and security studies'.

${ }^{86}$ Young, 'The logic of masculinist protection'.

${ }^{87}$ Bertrand, 'Can the subaltern securitize?'; Kronsell, 'Method for studying silences'.

${ }^{88}$ Snedker, 'Altruistic and vicarious fear of crime'.
} 
conducted indicated that women had a greater propensity to look at security and threat from different perspectives. For example, a group of middle-aged Hindu women participants identified a variety of threatened groups within society, including older people, parents, British Asians, and other non-white people. They identified racism as a major threat for them and their children, but suggested that others in Britain would not prioritise racism as a threat - as one of them put it, 'I think we probably look at things in a slightly different way.' Similarly, a young white woman from Bristol explained: the ranking of different threats is difficult because 'it is personal for each person, it's different'; we did not identity such patterns in the discussions among men. ${ }^{89}$ It could be that this reflects a stronger group-based gender consciousness among women, which may arise in part from the gendered and intersectional microaggressions that women face on a day-to-day basis. $^{90}$

This section again demonstrates the utility of mixed methods informed by consideration of the insights offered by public opinion and FSS research. Gauging the number of issues identified as security threats in the survey showed us that women perceive more threats, particularly for everyday issues of crime at the national and global levels. But in looking beyond the apparent 'gaps' themselves and analysing discussions in the focus groups we suggest that they represent something different and more subtle than women simply being more threatened than men: that women are more able and more disposed to consider security threats from a range of different viewpoints beyond their own. This is also consistent with the survey evidence on women's somewhat different emphases in definitions of 'security threat', showing how public opinion and FSS research can complement each other as well as highlight gaps and tensions in the extant research.

\section{Government's ability to deal with security threats}

A key aspect of differences between men and women in our data is opinions of the extent to which these threats can be mitigated by government, which we argue tells us more about the political implications of threat perceptions than whether or not women favour an immediate belligerent response to military or terror threats. The focus groups showed that although respondents felt the responsibility for addressing the threats they identified was spread across society, the primary actor should be the government. We also observed frustration from men and women with the effectiveness of UK government policies in tackling, or potentially exacerbating, a range of threats, from terrorism - 'Yes I mean if you feel really concerned about the terrorist threat I mean look at our foreign policies' - to anti-social behaviour - 'they should make a really strict law and show people, show that this is what happens and this punishment is for this person'.

The survey focused on a subset of 11 of the issues, including terrorism and identity theft, and looked at perceptions of the government's ability to deal with security threats in a different way. Respondents were asked about the government's present handling of each threat and then their expectations of the government's success in handling the threat in the future on a scale from 'very well' to 'very badly'. This gives us an indication both of differences in current perceptions of government's ability to deal with security threats and of optimism or pessimism about its ability to deal with those threats in the future - a gauge of likely effectiveness. Table A5 in the supplementary material shows analysis of perceptions of the government's current handling of the 11 threats. Differences between men and women are evident for 3 of the 11 issues, with two of those showing women judging the government more harshly than men: there are not systematic differences in perceptions.

\footnotetext{
${ }^{89}$ It is also possible that there are other differences between women and men that account for these gender gaps in perceptions of threat, which do not emerge clearly in small-N focus group discussion. We present some analysis and discussion of this evidence, using the survey data, in the Appendix, Table A4 in the supplementary material. It shows that gender differences in attitudinal and demographic variables appear not to be the explanation for the results shown in Table 2.

${ }^{90} \mathrm{We}$ thank Reviewer 1 for suggesting this as a possible explanation.
} 
Table 3. Perceptions of government effectiveness in handling threats in the future.

\begin{tabular}{|c|c|c|c|c|c|c|c|c|c|c|c|c|}
\hline \multirow[b]{2}{*}{ Woman } & \multicolumn{2}{|c|}{ Financial crisis } & \multicolumn{2}{|c|}{ Crime } & \multicolumn{2}{|c|}{ Cybercrime } & \multicolumn{2}{|c|}{ Identity theft } & \multicolumn{2}{|c|}{ Terrorism } & \multicolumn{2}{|c|}{ Religious extremism } \\
\hline & $.27(.05)^{\star}$ & $.20(.05)^{\star}$ & $.23(.05)^{\star}$ & $.19(.05)^{\star}$ & $.07(.05)$ & $.05(.05)$ & $.07(.05)$ & $.04(.05)$ & $.09(.04)^{\star}$ & $.06(.04)$ & $.16(.05)^{\star}$ & $.15(.05)^{\star}$ \\
\hline Authoritarianism & & $.26(.08)^{\star}$ & & $.19(.07)^{\star}$ & & $.16(.07)^{\star}$ & & $.25(.07)^{\star}$ & & $.18(.07)^{\star}$ & & $.32(.08)^{*}$ \\
\hline Internal efficacy & & $-.26(.12)^{*}$ & & $-.23(.11)^{*}$ & & $-.15(.12)$ & & $-.16(.12)$ & & $-.17(.10)^{\#}$ & & $.03(.13)$ \\
\hline External efficacy & & $.23(.13)^{\#}$ & & $.00(.12)$ & & $.22(.12)^{\#}$ & & $.13(.12)$ & & $.05(.11)$ & & $-.09(.14)$ \\
\hline Approval of current govt. & & $-.49(.10)^{*}$ & & $-.07(.09)$ & & $.15(.09)$ & & $.17(.09)^{\#}$ & & $.24(.08)^{\star}$ & & $.14(.10)$ \\
\hline Age & & $-.67(.11)^{\star}$ & & $-.42(.10)^{*}$ & & $-.41(.10)^{*}$ & & $-.40(.10)^{*}$ & & $-.36(.09)^{\star}$ & & $-.25(.11)^{\star}$ \\
\hline Conservative id & & $.01(.07)$ & & $-.09(.07)$ & & $-.01(.07)$ & & $.00(.07)$ & & $-.06(.06)$ & & $-.12(.08)$ \\
\hline Labour id & & $.10(06)$ & & $-.05(.06)$ & & $.06(.06)$ & & $.04(.06)$ & & $.03(.05)$ & & $-.10(.06)$ \\
\hline No party id & & $.06(.09)$ & & $-.06(.08)$ & & $-.04(.08)$ & & $-.01(.08)$ & & $-.03(.07)$ & & $-.13(.09)$ \\
\hline Constant & $.46(.04)^{\star}$ & $.79(.13)^{\star}$ & $.19(.03)^{\star}$ & $.48(.12)^{\star}$ & $.21(.03)^{\star}$ & $.24(.12)^{\star}$ & $.27(.03)^{\star}$ & $.26(.12)^{\star}$ & $-.04(.03)$ & $.03(.11)$ & $.25(.04)^{\star}$ & $.23(.13)^{\#}$ \\
\hline $\mathrm{N}$ & 1712 & 1712 & 1717 & 1717 & 1536 & 1536 & 1572 & 1572 & 1675 & 1675 & 1610 & 1610 \\
\hline \multirow[t]{2}{*}{ Adjusted $\mathrm{R}^{2}$} & .02 & .06 & .01 & .03 & .00 & .02 & .00 & .02 & .00 & .02 & .01 & .02 \\
\hline & \multicolumn{2}{|c|}{ Immigration } & \multicolumn{2}{|c|}{ Islamophobia } & \multicolumn{2}{|c|}{ Far Right } & \multicolumn{2}{|c|}{ Climate change } & \multicolumn{2}{|c|}{ Global warming } & & \\
\hline Woman & $.18(.06)^{*}$ & $.15(.06)^{\star}$ & $.13(.05)^{*}$ & $.10(.05)^{\#}$ & $.13(.05)^{\star}$ & $.11(.05)^{\star}$ & $.13(.05)^{\star}$ & $.11(.05)^{\star}$ & $.12(.05)^{\star}$ & $.08(.05)^{\#}$ & & \\
\hline Authoritarianism & & $.48(.09)^{\star}$ & & $.25(.08)^{*}$ & & $.17(.07)^{\star}$ & & $.14(.07)^{\star}$ & & $.15(.08)^{\#}$ & & \\
\hline Internal efficacy & & $-.31(.14)^{*}$ & & $-.18(.13)$ & & $-.08(.12)$ & & $-.04(.11)$ & & $-.20(.12)$ & & \\
\hline External efficacy & & $.07(.15)$ & & $-.10(.14)$ & & $.23(.12)^{\#}$ & & $.33(.12)^{\star}$ & & $.14(.13)$ & & \\
\hline Approval of current govt. & & $.20(.11)^{\#}$ & & $.16(.10)$ & & $.11(.09)$ & & $-.05(.09)$ & & $.08(.10)$ & & \\
\hline Age & & $-.08(.12)$ & & $-.37(.11)^{*}$ & & $-.31(.10)^{*}$ & & $-.59(.10)^{\star}$ & & $-.33(.11)^{\star}$ & & \\
\hline Conservative id & & $.10(.08)$ & & $.04(.08)$ & & $.04(.07)$ & & $-.12(.07)^{\#}$ & & $-.03(.07)$ & & \\
\hline Labour id & & $-.07(.07)$ & & $.09(.06)$ & & $.08(.06)$ & & $-.11(.06)^{\#}$ & & $.04(.06)$ & & \\
\hline No party id & & $-.04(.10)$ & & $-.00(.09)$ & & $.01(.09)$ & & $-.08(.08)$ & & $-.05(08)$ & & \\
\hline Constant & $.50(.04)^{\star}$ & $.35(.14)^{\star}$ & $.16(.04)^{\star}$ & $.23(.13)^{\#}$ & $.15(.03)^{\star}$ & $.07(.12)$ & $.15(.03)^{\star}$ & $.31(.12)^{\star}$ & $.19(.03)^{\star}$ & $.28(.12)^{\star}$ & & \\
\hline $\mathrm{N}$ & 1707 & 1707 & 1418 & 1418 & 1442 & 1442 & 1593 & 1593 & 1566 & 1566 & & \\
\hline Adjusted $\mathrm{R}^{2}$ & .01 & .03 & .00 & .02 & .00 & .02 & .00 & .03 & .00 & .01 & & \\
\hline
\end{tabular}

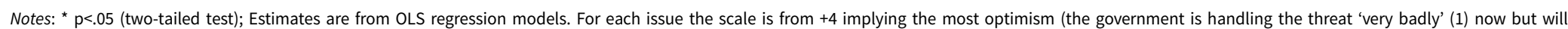

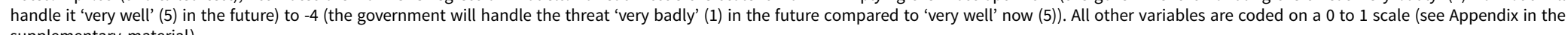
supplementary material).

Source: ICM Survey, Security in an Age of Austerity, 6-15 June 2012. 
Next, we turn to perceptions of the UK government's ability to deal with the 11 security threats in the future. Table 3 reports the results of regression analyses in which the dependent variables are the difference between respondents' perceptions of future and current evaluations of handling of each threat. Positive scores indicate greater expectations of future government effectiveness than perceptions of current government effectiveness, zero indicates no difference, and negative scores that expectations of future government effectiveness are lower than current government effectiveness (for further details see notes to Table 3). On all 11 issues there was a general 'optimism bias' (see Table A6 in the supplementary material), or tendency to think that the government would handle the threat better in the future than currently, but the coefficients for gender in Table 3 show that being a woman had an additional statistically significant and positive effect on perceptions of future government effectiveness for nine of the 11 issues (including terrorism). When we control for other factors such as political efficacy and approval of the current government, in the second column of results for each issue in Table 3, the effects for women remain significant $($ at $\mathrm{p}<.10)$ for 8 of the 11 issues. ${ }^{91}$ While these results are consistent with Patricia Gwartney's $^{92}$ and Salvatore and Gorman's ${ }^{93}$ findings regarding gender differences in optimism about the government's effectiveness in tackling terrorism, we find these differences to be present almost regardless of the issue. This is despite the qualitative evidence that women are more likely to say of threats such as terrorism that there is little the government can do. ${ }^{94}$

This evidence suggests that women's objections to military action are not based on a broad scepticism about government's ability to handle security threats. In addition, optimism as a result of women being socialised to accept greater threat, ${ }^{95}$ or from the subordinate role of women $v i s$ - $a$-vis their masculine protectors in which they cede critical distance from the decision-making autonomy within the authoritarian security state, ${ }^{96}$ may be factors but neither fully solves the puzzle. Women's greater optimism also appears connected to a combination of perceptions of vulnerability and the kinds of differences in the intensity with which threats are felt that the focus group data suggested.

As further evidence on vulnerability, the survey asked about respondents' confidence in themselves and in the government in the event of a terrorist attack. On both measures men displayed significantly more confidence than women, reflecting perceptions of invulnerability, but especially in their confidence that they as an individual would know what to do (see Table A7 in the supplementary material). For men there was little difference in their confidence in themselves and their confidence in government, whereas women displayed far more confidence in government than in themselves. As we have shown in Table 3, women were also more optimistic about the government's likely effectiveness in dealing with terrorism in the future. This is another

\footnotetext{
${ }^{91}$ Based on previous research on influences on perceptions of security threats. See, for example, Harold Clarke, David Sanders, Marianne Stewart, and Paul Whiteley, Performance Politics and the British Voter (Cambridge: Cambridge University Press, 2009); Karen Stenner, The Authoritarian Dynamic (Cambridge: Cambridge University Press, 2005). We control for authoritarianism, age, overall satisfaction with the government, party identification, and political efficacy (internal and external). These are all coded on scales from 0 to 1 (see Appendix in the supplementary material). Political efficacy pertains to perceptions that ordinary people have an influence on political decision-making, with the distinction between internal and external efficacy being whether an individual considers him or herself sufficiently cognisant and informed to participate in politics (internal efficacy) as opposed to the extent to thinking that government is responsive to the public in general (external efficacy).

${ }^{92}$ Gwartney, 'Race, gender, class and perceptions of terrorism'.

${ }^{93}$ Salvatore and Gorman, 'Gender-based perceptions of the 2001 anthrax attacks'.

${ }^{94}$ Internal efficacy may offer a partial explanation for differences (see Appendix, Table A4): we examined whether the influence of internal efficacy varied between men and women. We found statistically significant interactions for three of the 11 issues $($ at $\mathrm{p}<.10)$ that indicated no differences in perceptions of future government effectiveness between men and women with the highest internal efficacy but differences - with women being more positive - at lower levels of internal efficacy.

${ }^{95}$ Gilchrist et al., 'Women and the "fear of crime"'; Hudson et al., Sex and World Peace.

${ }^{96}$ Young, 'The logic of masculinist protection'.
} 
potential example of the logic of masculinist protection. ${ }^{97}$ Thus, perceptions of vulnerability ${ }^{98}$ seem to be part of the explanation for women's greater optimism about the efficacy of government action.

Table 3 also suggests that the ways in which socialisation affects perceptions of threats such as from crime may be more complex than currently allowed: women may judge other threats relative to those where we have seen they perceive most risk, such as online crime. The everyday risk around threats like online crime appears to contribute to the pragmatism we observe about other threats, feeding into women's optimism about future handling of those threats. We say this because identity theft and online crime were two of the most frequently raised security threats by women in the focus groups, and the survey data show that online crime was one of the issues that women were consistently more likely to identify as a security threat than men. Yet differences between men and women on the likely future ability of government to mitigate these threats are also least pronounced in Table 3. By contrast women were more optimistic about the future on issues they identified as threats in similar numbers to men, such as environmental issues, immigration, Islamophobia, and the Far Right. That identity theft and online crime were also issues about which women were most threatened suggests that there are not gender differences in perceptions of government's future effectiveness on issues for which women feel similarly intensely threatened to men.

Before concluding, we note that the gendered patterns we see in the qualitative and quantitative data seem to transcend religion, lifestage, and region. ${ }^{99}$ For example, in the focus group discussion among Hindu women from which we quoted above, while the racism they mention may have been more salient to them than for the white woman from Bristol in the quote that followed, what was more striking than race was the tendency of these and other women to consider security threats from perspectives beyond their own. This was in contrast to men. The large-N survey data provide additional evidence. We looked at possible intersectionality of gender and age, religion, and region of residence: none of this analysis indicated that any of these factors affected the relationships between gender and the dependent variables we examine. ${ }^{100}$ This is not to rule out any possibility of intersectionality: the absence of evidence could be due to our focus on descriptive characteristics of individuals such as age and region, and our limited ability to examine race, rather than, for example, Sa'ar et al.'s examination of, 'different social locations, different types of violence and different types of knowledge'. ${ }^{101}$ There may also be intersectional influences on perceptions of security that differ among women and among men; they are beyond the scope of this article but should be explored in future research.

\section{Conclusion}

Research on differences in perceptions of security threats between men and women consistently presents the puzzle that, while women and men do not occupy different political universes on these issues, men identify fewer threats but are more likely to favour aggressive responses to address those threats than women. Indeed, this article has replicated those kinds of findings in Britain in 2012. We could have searched for the 'mechanisms' that might account for these gender differences. But in taking the novel step of bringing public opinion and FSS research into closer conversation our analysis demonstrates that this would be premature: what lies behind these apparent gaps in opinion is complex and first demands careful interpretation and scrutiny.

\footnotetext{
${ }^{97}$ Ibid.

${ }^{98}$ Jocelyn Hollander, 'Vulnerability and dangerousness: The construction of gender through conversation about violence', Gender \& Society, 15:1 (2001); Snedker, 'Altruistic and vicarious fear of crime'.

${ }^{99}$ Most groups were exclusively composed of men or women; five were of mixed sex but the same lifestage. Discussion of security threats in these mixed groups was consistent with discussion in homogeneous groups.

${ }^{100}$ In quantitative terms, we examined whether the effects of gender in Tables 1-3 were moderated by age, religion (Muslim, non-Muslim), or region (Scotland, Wales, North, Midlands, South, London) but found no evidence that they were.

${ }^{101} \mathrm{Sa}$ 'ar et al., 'Between a gender and a feminist analysis', p. 66.
} 
For example, we have shown that gender differences on the issues of war and conflict that have dominated previous research are not those where there are the greatest differences, nor are they confined to issues characterised by physical threat. Instead, differences are most evident for perceptions of everyday issues such as crimes of various kinds. In addition, women's 'greater sense of threat' appears to come not simply from seeing more threats in their environment but from an ability or willingness to put themselves in the position of others that has not previously been recognised. Indeed, we have suggested that it is men who feel more threatened in terms of being in a constant state of alert and feeling threats more intensely. Finally, women also appear to be more pragmatic and optimistic about what can be done by government to mitigate threats, but the evidence we have presented suggests that this is not simply due to greater risk aversion, nor because women have less confidence in themselves or are detached and uncritical of the masculinist protection of the state. The complex interplay of these factors needs much more investigation.

These specific findings are from Britain in 2012. Their substantive implications clearly need further testing in other contexts. But it would be surprising, and interesting, if strong findings in our analysis such as women's tendency to be optimistic about government's ability to handle threats in the future were not evident in different contexts in Britain or in different countries. More importantly, there is a clear need for further research to explore the underlying explanations for these differences in much greater depth. These explanations are likely to be contextual and mediated by a range of individual and community factors - and therefore not necessarily generalisable in a straightforward way. But as the engagement with FSS perspectives has shown, there is a real need for more sophisticated explorations of any 'gender gaps' we might identify.

Indeed, our broader argument is about the methodological implications of our research. Future research requires a move towards the methodological pluralism we have employed, which can identify complex relationships and factors while maintaining a critical perspective that is sensitive to gendered power relations and knowledge constructs. This approach would embrace potential ontological and epistemological tensions between the different methodologies reflected in public opinion and FSS research to-date in order to identify and understand 'variable relationships of co-constitution, signification and performativity' and generate opportunities for creative dialogue across disciplinary and methodological borders. ${ }^{102}$ It would interrogate the ways in which security discourses - and ideas about masculinity and femininity - constitute, rather than simply represent, security realities for different people by paying attention to the relationship between security and identity. ${ }^{103}$ Most immediately this article's findings suggest that further research is needed to better understand how men think about aggression and their masculinity, why they appear to feel more threatened, and what rationalities make possible their privileging of aggressive responses.

This research should also include a consideration of the influence of other potential factors we have been unable to consider in this article, such as race and a stronger group-based consciousness among women. Research in the UK and US has also demonstrated an influence of newspapers and television on perceptions of security threats. ${ }^{104}$ But questions of their relationship to differences in media consumption among women and men, or to differences in the processing of media messages, have not been explored. This should go beyond perceptions of security threats to look at media influence on the kinds of differences in fearfulness and pragmatism that we have

\footnotetext{
${ }^{102}$ Barkin and Sjoberg, 'Calculating critique', p. 868.

${ }^{103}$ Maria Stern, Naming Security - Constructing Identity: 'Mayan Women' in Guatemala on the Eve of 'Peace' (Manchester: Manchester University Press, 2005).

${ }^{104}$ See, for example, Dan Cassino, Fox News and American Politics: How One Channel Shapes American Politics and Society (London: Routledge, 2016); Shah Nister Kabir, Sharifah Nurul Huda Alkaff, and Michael Bourk, 'Iconizing "Muslim terrorism" in a British newspaper and public perception', Journal of Muslim Minority Affairs, 38:2 (2018); Stevens and Vaughan-Williams, Everyday Security Threats.
} 
indicated in our analysis. Further research will also enable us to understand more fully how effective securitising discourses are, ${ }^{105}$ and how gendered power relations shape this process. ${ }^{106}$ Finally, returning to Enloe's maxim that 'the personal is international', we need to find out what determines how people identify threats as local, national, and global, why they exclude other vulnerabilities, and what the relationships are between security at the local, national and global levels.

Engaging with FSS approaches could enrich and transform public opinion accounts of the differences between men and women's perceptions of security. By the same token, engaging with public opinion methodologies would allow FSS to examine the interconnected relationships between different threats that it often postulates but tends to eschew testing. We advocate a research agenda in international security studies that systematically and comprehensively engages both literatures and utilises their methodological expertise. This would allow us to go beyond the gender-gap stalemate in which we reproduce findings but get no closer to explaining them, and instead generate sophisticated knowledge about the relationship between men and women's perceptions of security and the security discourses that constitute those opinions and lived experiences.

Acknowledgements. The research in this article was supported by the Economic and Social Research Council grant Public Perceptions of Threat in Britain: Security in an Age of Austerity (ES/J004596/1). Anonymised interview transcripts from focus group participants, who consented to data sharing, the survey data, plus additional supporting information are available from the UK Data Service, subject to registration, at: 10.5255/UKDA-SN-851004.

Supplementary material. To view supplementary material for this article, please visit: \{https://doi.org/10.1017/eis.2020.14)

Daniel Stevens is Professor of Politics at the University of Exeter. His research addresses questions around public opinion and political communication and has been funded by the British Academy and the ESRC. He is co-author of Everyday Security Threats (Manchester University Press, 2016) and Truth in Advertising: Lies in Political Advertising and How They Affect the Electorate (Lexington Press, 2018), which won the PSA's Richard E. Neustadt book prize.

Sarah Bulmer is Senior Lecturer in Politics at the University of Exeter. She works in the field of Critical Military Studies. Sarah's research focuses on military subjectivity and the critical potential of engaging with the experiences of military personnel, and has been funded by the AHRC and the Volkswagen Foundation. She is currently writing a monograph called Queering the Military: Sexuality in the Armed Forces, which interrogates the regulation of gender and sexuality in the British armed forces. Sarah is also interested in experiences of military-civilian transition for veterans and, with collaborator David Jackson, she is exploring new methods and epistemologies for researching veterans' embodied experiences.

Susan Banducci is a Professor of Politics at the University of Exeter, a co-director of the Exeter Q-Step Centre, and a Turing Fellow. Her research addresses questions of inequalities in political behaviour, bringing together individual and institutional explanations, and has been funded by the British Academy, ESRC, and Horizon 2020. She has authored and co-authored articles in journals such as the British Journal of Political Science; European Journal of Political Research; and Public Opinion Quarterly. She will lead the Questionnaire Design Team for a module on gender attitudes in Round 11 of the European Social Survey.

Nick Vaughan-Williams is Professor of International Security at the University of Warwick, UK. In 2015 he received the Philip Leverhulme Prize for Politics and International Studies. His work on the international politics of borders, security, and migration has been funded by the British Academy, UK Economic and Social Research Council, and Leverhulme Trust. He is author of Vernacular Border Security (Oxford University Press, 2021); Europe's Border Crisis (Oxford University Press, 2015); and Border Politics (Edinburgh University Press, 2009) and co-author of Reclaiming Migration (Manchester University Press, 2021); Critical Security Studies (Routledge, 2021); and Everyday Security Threats (Manchester University Press, 2016).

\footnotetext{
${ }^{105}$ Barry Buzan, Ole Wæver, and Jaap de Wilde, Security: A New Framework for Analysis (Boulder, CO: Lynne Rienner, 1997).

${ }^{106}$ Hansen, 'The Little Mermaid's silent security dilemma'.
}

Cite this article: Stevens, D., Bulmer, S., Banducci, S., Vaughan-Williams, N. 2021. Male warriors and worried women? Understanding gender and perceptions of security threats. European Journal of International Security 6, 44-65. https:// doi.org/10.1017/eis.2020.14 